DOI: https://doi.org/10.24127/ajpm.v10i4.4315

\title{
EFEKTIVITAS MODEL PEMBELAJARAN INKUIRI TERBIMBING DENGAN METODE JIGSAW TERHADAP HASIL BELAJAR ASSESMENT PEMBELAJARAN MATEMATIKA
}

\author{
Stefania Baptis Seto ${ }^{1 *}$, Maria Fatima Mei $^{2}$, Gregorius Taga ${ }^{3}$ \\ ${ }^{1,2,3}$ Universitas Flores, Ende, Indonesia \\ *Corresponding author. Jl. Sam Ratulangi, , 86316, Ende, Indonesia. \\ E-mail: stefaniseto@gmail.com ${ }^{\left.{ }^{*}\right)}$ \\ imajevan202019@gmail.com $^{2)}$
}

Received 13 October 2021; Received in revised form 17 November 2021; Accepted 27 December 2021

\begin{abstract}
Abstrak
Tujuan dari penelitian ini adalah untuk mengetahui pengaruh penggunaan model pembelajaran inquiri dengan metode kooperatif tipe jigsaw terhadap hasil belajar mata kuliah assesment pembelajaran matematika mahasiswa program studi Pendidikan matematika Universitas Flores. Penelitian yang dilakukan merupakan penelitian kuatitif tipe quasi experiment dan desain penelitian pretest-posttest control group design. Subjek penelitian adalah mahasiswa semester 6 program studi Pendidikan matematika Universitas Flores yang mengambil mata kuliah assesment pembelajaran matematika dan terbagi menjadi kelas kontrol dan kelas eksperimen. Instrumen tes yang digunakan dalam penelitian ini adalah tes uraian sebanyak 5 butir soal. Adapun teknik analisi data yang digunakan adalah uji-t dan uji ngain. Hasil penelitian menunjukkan bahwa model inkuiri terbimbing dan metode kooperatif tipe jigsaw efektif untuk meningkatkan hasil belajar mata kuliah assestmen pembelajaran matematika yang terlihat dari hasil uji t dimana nilai signifikansinya $0,000<0,05$. Selain itu peningkatan hasil belajar pada kelas eksperimen juga masuk dalam kategori sedang. Kombinasi model inkuiri terbimbing dan metode kooperatif tipe jigsaw mendorong mahasiswa untuk saling membantu dalam membangun konsep secara mandiri, sehingga konsep yang dipelajari menjadi lebih bermakna.
\end{abstract}

Kata kunci: Hasil belajar; inkuiri terbimbing; koopertif tipe jigsaw.

\begin{abstract}
The purpose of this study was to determine the effect of the use of the inquiry learning model with the jigsaw type cooperative method on the learning outcomes of the mathematics learning assessment course for students of the Mathematics Education study program at the University of Flores. This research is a quantitative research with a quasi-experimental type and a pretest-posttest control group design. The research subjects were 6th semester students of the Mathematics Education study program at the University of Flores who took the mathematics learning assessment course and were divided into a control class and an experimental class. The test instrument used in this study was a description test of 5 questions. The data analysis techniques used are $t$-test and n-gain test. The results showed that the guided inquiry model and the jigsaw type cooperative method were effective in improving learning outcomes of the mathematics learning assessment subject as seen from the t-test results where the significance value was $0.000<0.05$. In addition, the increase in learning outcomes in the experimental class is also in the medium category. The combination of the guided inquiry model and the jigsaw type cooperative method encourages students to help each other in constructing concepts independently, so that the concepts learned become more meaningful.
\end{abstract}

Keywords: Guided inquiry; jigsaw'a cooperative learning method; learning outcomes.

This is an open access article under the Creative Commons Attribution 4.0 International License 
DOI: https://doi.org/10.24127/ajpm.v10i4.4315

\section{PENDAHULUAN}

Suatu proses pembelajaran jika dipandang dari sudut pandang pendidik setidaknya berkenaan tentang 3 hal yaitu perencanaan, pelaksanaan, dan penilaian atau evaluasi. Ketiga hal tersebut harus dikuasai oleh pendidik atau guru dalam rangka untuk mencapai tujuan pembelajaran. Salah satu kompetensi yang dibahas lebih mendalam adalah terkait penilaian atau evaluasi. Kompetensi dalam melakukan penilaian cukup penting untuk dikuasai guru sebagai suatu langkah untuk menentukan apakah pembelajaran yang dilaksankan dikatakan berhasil. Penilaian adalah proses pengumpulan dan pengolahan informasi untuk mengukur pencapaian hasil belajar peserta didik (Kemendikbud, 2016). Oleh karena itu, secara khusus terdapat mata kuliah assesment pembelajaran pada program studi kependidikan di perguruan tinggi termasuk pada prodi pendidikan matematika.

Mata kuliah assesment pembelajaran menekankan pada kompetensi seorang calon pendidik untuk dapat menyusun instrumen penilaian secara komprehensif untuk menilai setiap kompetensi peserta didik (Sunardi, 2017). Oleh karena itu, mata kuliah ini menekankan pada produk berupa instrumen penilaian yang disusun oleh mahasiswa. Akan tetapi, berdasarkan penelitian pendahuluan diperoleh hasil yang kurang baik. Hasil dari penelitian pendahuluan menunjukkan bahwa lebih dari 50\% mahasiswa tidak mencapai kriteria minimal. Hal ini menunjukkan bahwa masih banyak mahasiswa calon guru yang belum paham terkait penyusunan assesment pembelajaran.

Rendahnya hasil belajar pada mata kuliah assesment pembelajaran didasari oleh tingkat partisipasi mahasiswa dalam perkuliahan yang rendah. Tingkat partisipasi mahasiwa ini berkenaan dengan ketertarikan mahasiswa dalam mengikuti perkuliahan. Seperti penjelasan Seto \& Bantas (2020), yaitu ketertarikan mahasiswa untuk mengikuti perkuliahan dapat berpengaruh pada pencapaian hasil belajar mahasiswa. Hal ini didasari oleh pembelajaran yang masih didominasi dengan metode konvensional atau satu arah dari dosen ke mahasiswa. Pembelajaran konvensional bertentang-an dengan kompetensi yang ingin dicapai melalui mata kuliah ini, yaitu mahasiswa diharapkan dapat menyusun suatu instrumen assesment yang memenuhi kriteria minimal. Pembelajaran secara konvensional cenderung mengakibatkan peserta didik menjadi pasif dan kurang berkembang (Rajagukguk \& Hazrati, 2021). Oleh karena itu, diperlukan suatu model ataupun metode pembelajaran lain yang dapat meningkatkan partisipasi belajar maupun hasil belajar mahasiswa.

Model pembelajaran yang memiliki kriteria baik untuk diterapkan dalam perkuliahan assesment pembelajaran adalah model inkuiri terbimbing. Hal ini didukung oleh beberapa penelitian yang menyimpulkan bahwa dengan mengaplikasikan model inkuiri terbimbing dapat meningkatkan hasil belajar mahasiswa (Saputra, Affandi, Husniati, \& Makki, 2020). Model pembelajaran inkuiri terbimbing memberikan penekanan pada proses mengkonstruksi suatu konsep secara mandiri sehingga konsep yang dipelajari menjadi lebih bermakna ((Hartini \& Yuliana, 2019) dan (Susilawati, Maula, \& Albar, 2021). Selain itu, model pembelajaran inkuiri terbimbing dapat diaplikasikan kepada setiap tipe mahasiswa baik yang berkemampuan 
tinggi, sedang, ataupun rendah (Kurniawati, Noer, \& Gunowibowo, 2019).

Disamping model pembelajaran, terdapat metode pembelajaran yang berkenaan dengan kegiatan operasional dalam pembelajaran. Metode pembelajaran dapat dipadukan dengan model pembelajaran untuk memperoleh hasil pembelajaran yang maksimal. Salah satu metode pembelajaran yang sesuai adalah metode kooperatif tipe jigsaw. Hal ini sesuai dengan penelitian sebelumnya yang menyimpulkan bahwa metode kooperatif tipe jigsaw dapat meningkatkan hasil belajar serta partisipasi belajar peserta didik ((Monalisa \& Trapsilasiwi, 2015), (Karimah, 2014), dan (Kahar, Anwar, \& Murpri, 2020). Metode kooperatif tipe jigsaw menekankan pada pembagian kerja dan penguasaan konsep dari masing-masing individu dalam kelompok (Saila, 2016).

Kolaborasi model dan metode pembelajaran dapat menjadi langkah untuk menwujudkan peningkatan hasil belajar yang terkonsentrasi pada kombinasi pembelajaran dalam kelas (Kahar et al., 2020). Metode kooperatif tipe jigsaw dapat dikombinasikan dengan model inkuiri terbimbing karena selain memahami konsep secara mandiri, peserta didik juga akan diarahkan untuk saling bekerja sama.

Berdasarkan pembahasan terkait model dan metode pembelajaran yang sesuai dengan permasalahan, belum ada penelitian yang menggabungkan keduanya dalam satu pembelajaran. Oleh karena itu, pada penelitian ini akan mengkaji efektivitas model pembelajaran inkuiri terbimbing dengan metode kooperatif jigsaw terhadap hasil belajar mahasiswa pada mata kuliah assesment pembelajaran matematika.

\section{METODE PENELITIAN}

Penelitian ini merupakan penelitian kuantitatif dengan desain quasi eksperiment. Adapun desain dari penelitian yang akan dilakukan, yaitu pretest-posttest control group design seperti pada Tabel 1.

Tabel 1. Desain eksperimen

\begin{tabular}{lccc}
\hline \multicolumn{1}{c}{ Kelas } & Pretest & Perlakuan & Posttest \\
\hline Eksperimen & E1 & $\mathrm{X}$ & E2 \\
Kontrol & K1 & & K2 \\
\hline
\end{tabular}

Berdasarkan Tabel 1, perlakuan (X) yang dimaksud adalah penerapan model pembelajaran inkuiri terbimbing dengan metode kooperatif jigsaw. Adapun prosedur dari penelitian setelah menentukan tujuan penelitian, yaitu menyusun perangkat pembelajaran dengan model inkuiri terbimbing dan metode kooperatif jigsaw, menentukan kelas eksperimen dan kelas kontrol, menyusun instrumen tes hasil belajar dan melakukan uji validitas maupaun reliabilitas dari instrumen tes, melaksanakan pembelajaran, melakukan tes hasil belajar, menganalisis nilai tes hasil belajar mahasiswa, dan diakhiri dengan menyimpulkan hasil penelitian.

Subjek dari penelitian ini mahasiswa semester 6 program studi pendidikan matematika, Universitas Flores yang menempuh mata kuliah assesment pembelajaran matematika. Jumlah subjek penelitian adalah 68 mahasiswa yang terbagi menjadi 2 kelas (eksperimen dan kontrol). Penentuan kelas eksperiman dan kelas kontrol dilakukan dengan menggunakan cluster random sampling.

Teknik pengumpulan data yang digunakan dalam penelitian ini adalah dengan teknik tes. Adapun instrumen yang digunakan adalah tes hasil belajar mahasiswa yang telah memenuhi kriteria valid dan reliabel. Berdasarkan 
teknik pengumpulan data yang digunakan maka data yang diperoleh berupa nilai tes hasil belajar mahasiswa.

Data yang diperoleh kemudian dianalisis dengan metode statistik deskriptif dan inferensial. metode statistik inferensial yang digunakan yaitu uji-t yang dilanjutkan dengan uji $n$-gain. Uji n-gain dilakukan jika hasil dari uji t menunjukkan bahwa teradapat peningkatan hasil belajar mahasiswa. Nilai N-gain diperoleh melalui perhitungan dengan sesuai dengan rumus 1 .

$N-$ Gain Score $=\frac{\text { Postest Score }- \text { Pr etest Score }}{\text { Maximum Score }- \text { Pr etest Score }}$

Setelah diperoleh nilai n-gain dari masing-masing subjek penelitian kemudian dihitung rata-rata dari nilai $n$ gain tersebut dan hasilnya diinterpretasikan sesuai dengan Tabel 2 .

Tabel 2. Interpretasi dari nilai $N$-Gain

\begin{tabular}{cc}
\hline Nilai N-Gain $\mathbf{( N )}$ & Kategori \\
\hline$N>0,7$ & Tinggi \\
$0,3<N \leq 0,7$ & Sedang \\
$N \leq 0,3$ & Rendah \\
\hline
\end{tabular}

(Hartati, 2016)

\section{HASIL DAN PEMBAHASAN}

Hasil uji coba instrumen tes hasil belajar menunjukan bahwa dari 10 butir soal terdapat 5 butir soal yang tidak valid. Kelima butir soal tersebut kemudian ditentukan nilai reliabilitasnya dan diperoleh hasil sebesar 0,870 sehingga kelima butir tes hasil belajar tersebut sudah layak digunakan.

Setelah dilakukan tes hasil belajar terhadap subjek penelitian kemudian dilakukan uji normalitas dan uji homogenitas sebagai prasyarat dari uji-t dengan menggunakan SPSS. Adapun hasil dari normalitas dengan $\alpha=0,05$ dapat dilihat pada Tabel 3.
Tabel 3. Hasil uji normalitas

\begin{tabular}{lccc}
\hline \multicolumn{1}{c}{ Kelas } & \multicolumn{3}{c}{ Shapiro-Wilk } \\
& Statistic & df & Sig. \\
\hline Eksperimen & .975 & 34 & .618 \\
Kontrol & .966 & 34 & .350 \\
\hline
\end{tabular}

Berdasarkan Tabel 1, dapat dilihat pada nilai signifikansi yaitu baik kelas eksperimen maupun kelas kontrol memperoleh signifikansi lebih dari $\alpha$ $(0,05)$. Oleh karena itu, dapat disimpulkan bahwa kedua kelas berdistribusi normal. Selanjutnya, untuk uji homogenitas diperoleh nilai sgnifikansi sebesar 0,325 (lebih dari 0,05), sehingga disimpulkan bahwa subjek penelitian berasal dari populasi yang homogen.

Setelah dilakukan uji prasyarat kemudian dilanjutkan dengan uji-t. Hipotesis dari uji-t, yaitu:

Ho : Tidak terdapat perbedaan ratarata hasil belajar dari kelas eksperimen dan kelas kontrol

H1 : terdapat perbedaan rata-rata hasil belajar dari kelas eksperimen dan kelas kontrol

Adapun hasil dari uji-t dapat dilihat pada Tabel 4.

Tabel 4. Hasil uji-t

\begin{tabular}{lccc}
\hline & \multicolumn{3}{c}{ t-test for Equality Means } \\
\cline { 2 - 4 } & $t$ & $d f$ & $\begin{array}{c}\text { Sig. } \\
(2-\text { Tailed) }\end{array}$ \\
\hline $\begin{array}{l}\text { Equal Variances } \\
\text { Assumed }\end{array}$ & 2.691 & 66 & .009 \\
$\begin{array}{l}\text { Equal Variances } \\
\text { not assumed }\end{array}$ & 2.691 & 65.15 & .009 \\
\hline
\end{tabular}

Hasil yang disajikan pada Tabel 4, menunjukkan bahwa nilai dari .Sig (2Tailed) adalah sebesar 0,009 dan kurang dari 0,05. Oleh karena itu, Ho ditolak atau dapat disimpulkan bahwa terdapat perbedaan hasil belajar antara kelas eksperimen dan kelas kontrol. Lebih lanjut, rata-rata dari perbedaan nilai pretest dan posttest baik di kelas 
DOI: https://doi.org/10.24127/ajpm.v10i4.4315

eksperimen maupun kontrol menunjukkan rata-rata kenaikan nilai pada kelas eksperimen lebih besar. Hasil lebih lanjut dilihat dari uji n-gain pada kelas eksperimen. Rata-rata nilai $n$-gain pada kelas ekperimen adalah 0,34 atau berada pada kategori sedang.

Hasil uji-t menunjukkan bahwa kombinasi dari model inkuiri terbimbing dan metode kooperatif tipe jigsaw memberikan pengaruh dalam meningkatkan hasil belajar pada mata kuliah assesment pembelajaran matematika. Hal ini sesuai dengan hasil penelitian sebelumnya, yaitu model pembelajaran inkuiri menekankan pada pembelajaran yang berpusat pada peserta didik sehingga menjadikan mahasiswa dapat mengkonstruksi pengetahuan dengan cara yang lebih baik (Saputra et al., 2020).

Hasil penelitian juga menunjukkan bahwa penggunaan model inkuiri terbimbing membuat mahasiswa menjadi lebih memahami konsep dalam mata kuliah assesment pembelajaran matematika. Model inkuiri terbimbing dapat meningkatkan kemampuan mahasiswa dalam menelaah dan mengidentifikasi suatu permasalahan serta menganalisis kebenaran jawaban dan mengklarifikasi informasi (Kurniawati et al., 2019).

Hasil dari penelitian juga menunjukkan pengaruh metode kooperatif tipe jigsaw untuk meningkatkan hasil belajar pada mata kuliah assesment pembelajaran matematika. Saat terlibat dalam kegiatan pembelajaran kooperaif tipe jigsaw, mahasiswa akan lebih mempelajari sub bagian materi mereka secara mendalam (Siregar \& Khayroiyah, 2019).

Metode kooperatif tipe jigsaw memiliki kelebihan untuk mencapai pemerataan materi dalam waktu yang singkat serta mendorong mahasiswa untuk berbicara dan mengemukakan pendapat (Lubis, 2020). Hal ini juga mendorong terjadinya pembelajaran bermakna karena mahasiswa tidak hanya menerima, namun juga mencari, memperoleh, dan menyampaikan suatu konsep. Selain itu, metode kooperatif tipe jigsaw dapat mendorong mahasiswa untuk saling membantu sehingga ketercapaian pemahaman untuk mahasiswa menjadi lebih seragam (Septiani \& Qohar, 2020).

Kombinasi antara model inkuiri terbimbing dan metode kooperatif tipe jigsaw memberikan peningkatan hasil belajar dengan kategori sedang. Hal ini menunjukkan bahwa kombinasi keduanya dapat dijadikan suatu alternatif dalam pelaksanaan perkuliahan assesment pembelajaran matematika ataupun yang sejenis.

\section{KESIMPULAN DAN SARAN}

Berdasarkan hasil penelitian yang telah dilakukan dapat disimpulkan bahwa kombinasi model pembelajaran inkuiri terbimbing dan metode kooperatif tipe jigsaw dapat meningkatkan hasil belajar pada mata kuliah assesment pembelajaran matematika dengan kategori peningkatan rendah. Hal ini dikarenakan model pembelajaran inkuiri terbimbing dapat mendorong mahasiswa untuk membangun konsep secara mandi. Selain itu, metode kooperatif tipe jigsaw juga secara bersama mendorong untuk terciptanya suatu kerja sama yang baik.

Adapun saran untuk penelitian selanjutnya, yaitu untuk dapat meneliti jenis metode kooperatif lainnya untuk dikombinasikan dengan model inkuiri terbimbing. 


\section{DAFTAR PUSTAKA}

Hartati, R. (2016). Peningkatan Aspek Sikap Literasi Sains Siswa SMP Melalui Penerapan Model Problem Based Learning pada Pembelajaran IPA Terpadu. EDUSAINS, 8(1), 90-97. Retrieved from http://journal.uinjkt.ac.id/index.php /edusains

Hartini, \& Yuliana, R. (2019). Pengembangan Modul Pembelajaran Mata Kuliah Aljabar Linear Dengan Pendekatan Inkuiri Terbimbing di STKIP Paris Barantai Kotabaru. CENDEKIA: Jurnal Ilmiah Pendidikan, 7(2), 169-180.

https://doi.org/10.33659/cip.v7i2.1 31

Kahar, M. S., Anwar, Z., \& Murpri, D. K. (2020). Pengaruh Model Pembelajaran Kooperatif Tipe Jigsaw Terhadap Peningkatan Hasil Belajar. AKSIOMA: Jurnal Program Studi Pendidikan Matematika, 9(2), 279-295.

Karimah, S. (2014). Pengaruh Pembelajaran Kooperatif Tipe Jigsaw Terhadap Hasil Belajar Mahasiswa Pada Mata Kuliah Statistika Penelitian Pendidikan. Delta, 2(2), 68-73.

Kemendikbud. Peraturan Menteri Pendidikan dan Kebudayaan Nomor 23 Tahun 2016. , Pub. L. No. 23 (2016).

Kurniawati, K., Noer, S. H., \& Gunowibowo, P. (2019). Pengaruh Model Pembelajaran Inkuiri Terbimbing Terhadap Kemampuan Berpikir Reflektif dan Self Efficacy. Jurnal Pendidikan Matematika Unila, 7(1), 65-77.

Lubis, R. S. (2020). Pengaruh Penggunaan Model Pembelajaran Kooperatif Tipe Jigsaw Terhadap Hasil Belajar Mahasiswa. AXIOM,
09(2), 199-205.

Monalisa, L. A., \& Trapsilasiwi, D. (2015). Penerapan Model Pembelajaran Kooperatif Tipe Jigsaw Pada Pokok Bahasan Keterbagian Bilangan Bulat Untuk Meningkatkan Aktivitas Mahasiswa Semester VI Tahun Ajaran 2014-2015 Program Studi Pendidikan Matematika Fakultas Keguruan dan Ilmu Pendidikan Universit. Pancaran, 4(2), 173180.

Rajagukguk, W., \& Hazrati, K. (2021). Analisis Self-Efficacy Siswa dalam Penelitian Pembelajaran Matematika dengan Pendekatan Matematika Realistik dan Inkuiri. Jurnal Cendekia: Jurnal Pendidikan Matematika, 05(02), 2077-2089.

Saila, N. (2016). Penerapan Pembelajaran Kooperatif Tipe Jigsaw Pada Perkuliahan Matematika. Prosiding Seminar Nasional Pendidikan Matematika, 1, 208-216. Malang: Universitas Kanjuruhan Malang.

Saputra, H. H., Affandi, L. H., Husniati, \& Makki, M. (2020). Pengaruh Model Pembelajaran Inkuiti Terbimbing Terhadap Hasil Belajar Konseptual Mahasiswa Semester 1 FKIP Unram. Progres Pendidikan, 1(3), 143-153.

Septiani, I. T., \& Qohar, A. (2020).

Kerjasama Mahasiswa dalam Pembelajaran Kooperatif Tipe Jigsaw pada Mata Kuliah Pengantar Aljabar. Jurnal Didaktik Matematika, 7(1), 60-71. https://doi.org/10.24815/jdm.v7i1. 15365

Seto, S. B., \& Bantas, M. G. D. (2020). Pengaruh Motivasi Belajar dan Formasi Duduk Terhadap Hasil Belajar Mata Kuliah Asessmen 
DOI: https://doi.org/10.24127/ajpm.v10i4.4315

Pembelajaran Matematika. Jurnal

Cendekia: Jurnal Pendidikan

Matematika, 04(02), 526-533.

Siregar, T. J., \& Khayroiyah, S. (2019).

Pengaruh Model Pembelajaran

Kooperatif Tipe Jigsaw Terhadap

Kemampuan Pemecahan Masalah

Matematis Mahasiswa.

MathEducation Nusantara, 2(2), 150-154.

Sunardi. (2017). Analisis Jawaban Mahasiswa Dalam Menyelesaikan Soal Materi Bilangan Berpangkat Pada Mata Kuliah Asesmen Pembelajaran Matematika. Jurnal Pendidikan Matematika RAFA, 3(2), 131-145.

Susilawati, S., Maula, I., \& Albar, R. (2021). Model Pembelajaran Inkuiri Dengan ETD (Explain, TEst, Discussion) Dalam Pembelajaran Matematika di Masa Pandemi. Seminar Nasional Pendidikan Matematika, 2(1), 95104. 